\title{
Use of Novel Antidiabetic Agents in Patients with Type 2 Diabetes and COVID-19: A Critical Review
}

Djordje S. Popovic · Nikolaos Papanas · Anca Pantea Stoian •

Ali A. Rizvi · Andrej Janez · Manfredi Rizzo

Received: August 9, 2021 / Accepted: October 5, 2021 / Published online: October 26, 2021

(C) The Author(s) 2021

\section{ABSTRACT}

Severe acute respiratory syndrome coronavirus 2 (SARS-CoV-2) causes coronavirus disease 2019 (COVID-19). The latter is a pandemic that has the potential of developing into a severe illness manifesting as systemic

Djordje S. Popovic and Nikolaos Papanas contributed equally to the present work.

D. S. Popovic

Clinic for Endocrinology, Diabetes and Metabolic Disorders, Clinical Centre of Vojvodina, Novi Sad, Serbia

D. S. Popovic

Medical Faculty, University of Novi Sad, Novi Sad, Serbia

N. Papanas

Diabetes Centre-Diabetic Foot Clinic, Second Department of Internal Medicine, Democritus University of Thrace, University Hospital of Alexandroupolis, Alexandroupoli, Greece

\section{A. Pantea Stoian $(\bowtie) \cdot$ M. Rizzo}

Faculty of Medicine, Department of Diabetes, Nutrition and Metabolic Diseases, Carol Davila University of Medicine and Pharmacy, Bucharest, Romania

e-mail: ancastoian@yahoo.com

\section{A. A. Rizvi}

Division of Endocrinology, Metabolism, and Lipids, Emory University School of Medicine, Atlanta, GA, USA inflammatory response syndrome, acute respiratory distress syndrome, multi-organ involvement and shock. In addition, advanced age and male sex and certain underlying health conditions, like type 2 diabetes mellitus (T2DM), predispose to a higher risk of greater COVID-19 severity and mortality. This calls for an urgent identification of antidiabetic agents associated with more favourable COVID-19 outcomes among patients with T2DM, as well as recognition of their potential underlying mechanisms.

\section{A. A. Rizvi · M. Rizzo}

Division of Endocrinology, Diabetes and

Metabolism, University of South Carolina School of Medicine, Columbia, SC, USA
A. Janez
Department of Endocrinology, Diabetes and Metabolic Diseases, University Medical Centre Ljubljana, Faculty of Medicine, University of Ljubljana, Ljubljana, Slovenia

\section{Rizzo}
Department of Health Promotion Sciences Maternal and Infantile Care, Internal Medicine and Medical Specialties (PROMISE), University of Palermo, Palermo, Italy 
It is crucial that individuals with T2DM be kept under very stringent glycaemic control in order to avoid developing various cardiovascular, renal and metabolic complications associated with more severe forms of COVID-19 that lead to increased mortality. The use of novel antidiabetic agents dipeptidyl peptidase 4 inhibitors (DPP4i), sodium-glucose co-transporter 2 inhibitors (SGLT2i) and glucagon-like peptide 1 receptor agonists (GLP-1RAs) in subjects with T2DM may have beneficial effects on COVID-19 outcomes. However, relevant studies either show inconsistent results (DPP4i) or are still too few (SGLT2i and GLP-1RAs). Further research is therefore needed to assess the impact of these agents on COVID-19 outcomes.

Keywords: COVID-19; Dipeptidyl peptidase 4 inhibitors; Glucagon-like peptide 1 receptor agonists; Sodium-glucose co-transporter 2 inhibitors; Type 2 diabetes

\section{Key Summary Points}

Advanced age and male gender, as well as certain underlying health conditions, like type 2 diabetes mellitus, obesity and hypertension predispose to a higher risk of greater COVID-19 severity and mortality.

It is crucial that individuals with type 2 diabetes mellitus be kept under very stringent glycaemic control in order to avoid developing various cardiovascular, renal and metabolic complications associated with more severe forms of COVID-19 that lead to increased mortality.

The use of novel antidiabetic agents (dipeptidyl peptidase 4 inhibitors, sodium-glucose co-transporter 2 inhibitors and glucagon-like peptide 1 receptor agonists) in subjects with type 2 diabetes mellitus may have beneficial effects on COVID-19 outcomes.
Relevant studies either show inconsistent results (dipeptidyl peptidase 4 inhibitors) or are still too few (sodium-glucose cotransporter 2 inhibitors and glucagon-like peptide 1 receptor agonists) to make definitive conclusions; still, it seems that some novel antidiabetic agents have a favourable effect during the current pandemic.

\section{INTRODUCTION}

Severe acute respiratory syndrome coronavirus 2 (SARS-CoV-2) causes coronavirus disease 2019 (COVID-19), a new pandemic that is currently ongoing, with a dramatic impact in many countries $[1,2]$. In humans, the main route of SARS-CoV-2 transmission is through virus-bearing respiratory droplets [3, 4]. Its main entry receptor in human cells is angiotensinconverting enzyme 2 (ACE2) receptors which are expressed in alveolar lung cells, cardiac myocytes, vascular endothelium and other various types of cells $[5,6]$.

SARS-CoV-2 induces mild symptoms in the initial stage of infection which usually lasts about 2 weeks. However, it may develop into a more severe illness [7], including systemic inflammatory response syndrome, acute respiratory distress syndrome (ARDS), multi-organ involvement and shock [7]. Certain patient-related characteristics such as advanced age, male sex and underlying health conditions like cardiovascular disease, obesity and diabetes mellitus (DM) predispose to a higher risk of severe forms of COVID-19 and death $[8,9]$. The close association between diabetes and COVID-19 hospitalisation and mortality has been reported in multiple cohorts globally [10]. Diabetes is closely correlated with COVID-19 morbidity, including hospitalisation, critical illness and mortality [11].

Several potential mechanisms have been suggested, firstly that hyperglycaemia may promote viral proliferation. Elevated glucose 
increases SARS-CoV-2 replication, while glycolysis increases the production of mitochondrial reactive oxygen species (ROS) and activation of hypoxia-inducible factor $1 \alpha$ in human monocytes [12]. Indeed, poor glycaemic control predicts the need for medications and hospitalisation, as well as increased mortality $[13,14]$. Secondly, inflammation is the main feature of COVID-19 and increases insulin resistance [15]. Excess inflammation impacts both skeletal muscle and liver function [16]. Inflammation during COVID-19 might increase the risk of micro- and macrovascular complications originating from low-grade vascular inflammation in type 2 DM (T2DM) [17]. The results of a nationwide French study showed that micro- and macrovascular complications of DM were significantly associated with a high risk of mortality in patients with COVID-19 [18]. Thirdly, T2DM is associated with immunological dysregulation, potentially equivalent to accelerated aging, which could explain the poor prognosis in patients with T2DM and COVID-19 [19]. Fourthly, ACE2 is expressed in the endocrine pancreas where coronaviruses might damage the islets, potentially leading to hyperglycaemia $[20,21]$. Indeed, high glucose is found to persist up to 3 years after recovery from SARS [21]. Finally, some of the drugs often used in the clinical care of patients with COVID-19 (notably systemic corticosteroids and antiviral agents) may aggravate hyperglycaemia $[19,22]$.

Hence, it has been suggested that some of antidiabetic agents may be associated with more favourable COVID-19 outcomes and the potential underlying mechanisms [23]. This review summarises the current knowledge regarding the impact of three novel antidiabetic drug classes, namely dipeptidyl peptidase 4 inhibitors (DPP4i), sodium-glucose co-transporter 2 inhibitors (SGLT2i) and glucagon-like peptide 1 receptor agonists (GLP-1RAs), on clinical outcomes in patients with T2DM and COVID-19.

This article is based on previously conducted studies and does not contain any new studies with human participants or animals performed by any of the authors.

\section{SEARCH STRATEGY}

We performed an electronic search in PubMed, Google Scholar and SCOPUS databases in order to identify so far published studies using different combinations of the following keywords: COVID-19, coronavirus disease 2019, dipeptidyl peptidase 4 inhibitors, glucagon-like peptide 1 receptor agonists, mortality, outcomes, severity, sodium-glucose co-transporter 2 inhibitors, type 2 diabetes mellitus. Only publications in English language were considered.

\section{USE OF DPP4I IN PATIENTS WITH T2DM AND COVID-19}

Although it was speculated that SARS-CoV-2 might enter cells by binding to DPP4, recent studies have demonstrated that SARS-CoV-2 spike protein does not interact with human membrane-bound DPP4 (CD26) [24, 25]. Interestingly, DPP4i may have beneficial effects in patients with T2DM and COVID-19 through other mechanisms. The DPP4 enzyme has been shown to promote cell proliferation, CD86 expression and activation of the nuclear factor kappa-light-chain-enhancer of activated B cells signaling pathway, resulting in excessive inflammatory cytokine production [26, 27]. Additionally, DPP4 degrades endogenous GLP1 , which also harbours anti-inflammatory properties [28, 29]. Finally, DPP4 levels are significantly higher in obesity and metabolic syndrome $[30,31]$, which are some of the comorbidities associated with poorer outcomes in COVID-19.

Reports on outcomes of DPP4i in patients with T2DM and COVID-19 have not been remarkably consistent.

A multicentre retrospective observational study examined whether sitagliptin added to standard care in patients with T2DM 
hospitalised with COVID-19 conferred any benefit [32]. All patients had pneumonia and exhibited oxygen saturation below 95\% when breathing ambient air or receiving oxygen support [32]. The primary endpoints were discharge from the hospital/death and improved clinical outcomes (increase of at least 2 points on a 7-point scale) [32]. Add-on sitagliptin was associated with a significant reduction in mortality, enhanced clinical outcomes and a more significant number of hospital discharges [32]. Another work examined the impact of T2DM, different comorbidities, plasma glucose levels and antidiabetic medications on the survival of 90 patients with COVID-19 [33]. DPP4i were significantly and independently associated with a lower risk of mortality [33]. In a nationwide, multicentre observational study among 790 patients with T2DM at least 80 years of age with COVID-19 conducted in Spain, the use of DPP4i was an independent protector against in-hospital mortality [34]. The multinational retrospective cohort study, which included 7769 patients with T2DM and COVID-19 from a COVID-19 Research Network, had mortality as the primary outcome and the incidence of hospitalisation and respiratory complications as secondary outcomes [35]. In DPP4i users significant reductions in mortality (26\%) and in hospital admissions (20\%) were reported, while hospitalised patients who continued treatment with DPP4i had a $63 \%$ relative decrease in the incidence of mortality when compared with those who discontinued treatment with DPP4i [35].

Sainsbury et al. [36] performed a propensity score-matched cohort study to investigate whether SGLT2i prescription may be associated with COVID-19 compared to DPP4i. The primary outcome was confirmed or clinically suspected COVID-19. Ten thousand individuals with prescribed SGLT2i and about 15,000 with prescribed DPP4i were included; the main finding was a similar risk of confirmed or clinically suspected COVID-19 between users of these two classes of antidiabetic drugs [36]. In another multicentre retrospective cohort study performed in the UK and including about a thousand consecutive inpatients with COVID19 , there was no association between usage of different antidiabetic medications (including DPP4i, insulin, GLP-1RAs, metformin, sulfonylurea and SGLT2i) and the risk of death and/or ICU admission within 30 days of COVID-19 diagnosis [37]. In a retrospective observational study conducted in Italy on 159 patients with diabetes, there was no association between use of some antidiabetic medications (DPP4i, metformin, pioglitazone, insulin, sulfonylurea/ glinides, SGLT2i and GLP-1RAs) and the risk of either COVID-19 or case fatality, with the only exception of metformin, which was associated with the latter [38].

In another retrospective Belgian study of 73 patients with DM and COVID-19, non-survivors were equally often treated with DPP4i, sulfonylurea/glinides, SGLT2i, GLP-1RAs and insulin, but less often treated with metformin prior to admission in comparison to survivors [39]. An update of the results from the nationwide French Coronavirus SARS-CoV-2 and Diabetes Outcomes (CORONADO) study demonstrated that in 2796 patients with DM and COVID-19, routine metformin therapy was one of the predictors of discharge on day 28 and negatively associated with death within 28 days, while routine treatments with DPP4i, sulfonylurea/glinides, GLP-1RAs and insulin were not associated with those outcomes [40].

A large Korean study [41] included patients who had a positive test result for COVID-19, had been diagnosed with T2DM within the preceding 3 years and had at least one antidiabetic prescription within the preceding 180 days. Patients were classified into two groups: users of DPP4i with/without other antidiabetic drugs, and users of other non-insulin antidiabetic drugs, individually or in combination [41]. Unadjusted survival curves demonstrated a significant lower probability of all-cause mortality and severe COVID-19 manifestations among users of DPP4i; yet, DPP4i use was insignificantly associated with all-cause mortality and severe manifestations [41]. A 
case-control study by Fadini et al. showed no better outcomes among DPP4i users [42]. Similarly, a study based on medical charts of patients with fatal COVID-19 from different Italian districts reported that geographical differences in DPP4i use did not correlate with DM prevalence among COVID-19 deaths [43]. Consistent with such findings, in the secondary analysis of the CORONADO study, 2449 patients with T2DM hospitalised for COVID-19 in 68 French centres were included [44]. The primary outcome (tracheal intubation for mechanical ventilation and death within 7 days of admission) occurred at similar rates in users vs. non-users of DPP4i [44]. There was no significant association between DPP4i and the primary outcome on days 7 or 28. DPP4i did not reduce the risk of tracheal intubation and death [44].

In a multicentre retrospective analysis including subjects with T2DM who were hospitalised with COVID-19 in 16 Chinese hospitals [45], there was no significant association between in-hospital DPP4i use and 28-day allcause mortality. In addition, incidences and risks of secondary outcomes, including septic shock, ARDS or acute kidney/liver failure, were comparable between DPP4i users and non-users [45]. Further, in a retrospective, observational cohort study conducted among 717 patients with COVID-19 in Singapore, the fully adjusted model revealed that DPP4i use was associated with higher risk of ICU admission and mechanical ventilation among 76 subjects with T2DM [46]. Another population-based study used data from nationwide registries to examine the impact of DPP4i $(N=284)$ and GLP-1RAs $(N=370)$ compared with SGLT2i $(N=342)$ on the risk of hospital admission and severe outcomes of COVID-19 [47]. GLP-1RAs users had similar 30-day mortality to SGLT2i users $(3.3 \%$ vs. $3.7 \%$ ); both were lower vs. DPP4i users (8.6\%) [47]. The risks of hospital admission, ICU admission and mechanical ventilation were overall similar in DPP4i and GLP-1RAs users vs. SGLT2i users [47]. In addition, the recently published observational study from the
National COVID Cohort Collaborative (N3C), including 12,446 SARS-CoV-2-positive adults, with 60-day mortality as primary outcome, showed that both GLP1-RAs and SGLT2i use were associated with lower 60-day mortality compared to DPP4i use [48].

Finally, two meta-analyses have shown some beneficial effect of DPP4i on mortality among patients with DM and COVID-19, either restricted only to in-hospital use [49] or in general [50]. Ongoing trials should further elucidate the impact of DPP4i on COVID-19 morbidity and mortality among individuals with T2DM (e.g. NCT04542213). The obvious heterogeneity of all the aforementioned studies does not allow one to make firm conclusions, and additional large-scale studies are needed to provide definitive answers. The initial enthusiasm regarding the use of DPP4i, considering a potential role of DPP4 in COVID-19 onset and progression, has dwindled since subsequent studies have shown equivocal results. Overall, the use of DPP4i is considered safe among subjects with T2DM and COVID-19 but probably not the treatment of choice, taking also into account the neutral effect of DPP4i on cardiovascular outcomes [51].

\section{USE OF SGLT2I IN PATIENTS WITH T2DM AND COVID-19}

In patients with T2DM, SGLT2i treatment is associated with a favourable decrease in messenger ribonucleic acid (mRNA) levels of some cytokines and chemokines, such as tumour necrosis factor alpha, interleukin- 6 and monocyte chemoattractant protein 1 [52]. Additionally, SGLT2i may decrease lactate production due to reduced tissue oxygen demand, thereby potentially reducing viral entry by raising cytosolic pH [53]. On the other hand, SGLT2i could indirectly promote ACE2 activity [54], facilitating viral entry into cells. Undoubtedly, SGLT2i treatment can cause dehydration, ketoacidosis and acute kidney injury, especially among critically ill patients [55]. Either way, 
despite their cardiorenal beneficial effects in cardiovascular outcome trials [56], the use of these agents might be complicated and even potentially dangerous in patients requiring critical care.

In a retrospective, observational cohort study performed in Singapore, SGLT2i use was associated with a lower risk of mechanical ventilation among 76 subjects with T2DM [46]. Israelsen et al. demonstrated, using data from nationwide registries, that SGLT2i users had similar 30-day mortality as GLP-1RAs users, while for both it was lower than that of DPP4i users [47]. However, the risks of hospital admission, ICU admission and mechanical ventilation were overall similar for all of three studied drug classes [47]. The previously cited observational study showed that both GLP1-RAs and SGLT2i usage were associated with lower 60-day mortality in comparison to DPP4i usage [48]. Further, a Spanish multicentre observational study enrolling very old patients with T2DM and COVID-19 showed no association between preadmission use of SGLT2i and inhospital mortality [34].

Sainsbury et al. have shown that the risk of confirmed or clinically suspected COVID-19 between users of SGLT2i and DPP4i was similar [36], while in a multicentre retrospective cohort study conducted in the UK there was no association between use of different antidiabetic medications (including SGLT2i, DPP4i, insulin, GLP-1RAs, metformin and sulfonylurea) with the risk of death and/or ICU admission within 30 days of COVID-19 diagnosis [37]. An Italian retrospective observational study showed no association between usage of different antidiabetic medications (SGLT2i, DPP4i, metformin, pioglitazone, insulin, sulfonylurea/glinides and GLP-1RAs) and the risk of either COVID-19 or case fatality, except of metformin's association with lower rate of case fatality [38]. Finally, in another previously mentioned study from Belgium, enrolling patients with DM and COVID19 , survivors were equally often treated with SGLT2i, DPP4i, sulfonylurea/glinides and insulin, but more often treated with metformin prior to admission in comparison to non-survivors [39].

Of note, the Dapagliflozin in Respiratory Failure in Patients With COVID-19 (DARE-19) trial that aimed to analyse if cardio- and renoprotective benefits of dapagliflozin can be extrapolated to high-risk patients with COVID19 (with at least one cardiometabolic risk factor: hypertension, T2DM, atherosclerotic cardiovascular disease, heart failure and chronic kidney disease), but not critically ill [57]. Time to development of new or worsened organ dysfunction, or all-cause mortality, the composite endpoint of change in clinical status through day 30, as well as safety of dapagliflozin, were assessed. However, with some disappointment, trial results did not achieve statistical significance for the primary endpoints of prevention of organ dysfunction, reduction in all-cause mortality and improvement in the clinical status (ranging from early recovery to death) at 30 days [57].

In another randomised, parallel-arm, openlabel platform trial (mulTi-Arm Therapeutic Study in Pre-ICU Patients Admitted With Covid-19-Experimental Drugs and Mechanisms (TACTIC-E), patients with COVID-19 without need for ICU admission would be enrolled and randomised to either an experimental drug EDP1815 (preparation of a single strain of Prevotella histicola) or dapagliflozin $10 \mathrm{mg}$ daily plus ambrisentan (endothelin receptor antagonist) or standard care alone [58]. The primary outcome includes the composite endpoint of death, mechanical ventilation, extracorporeal membrane oxygenation, cardiovascular organ support or renal failure [58]. This study should scrutinise if the combination of dapagliflozin with ambrisentan may protect the patient against end-organ damage and modulate the pulmonary vascular response [58].

The shortage of dedicated large-scale studies analysing the role of SGLT2i among patients with T2DM and COVID-19 distracts us from any definite conclusions. However, a lot of hope has 
been invested in the potential beneficial role of SGLT2i in patients with T2DM and COVID-19, considering their proven metabolic and cardiorenal benefits [56]. Although SGLT2i may prevent or delay the development of cardiovascular and renal events, their practical use might be complicated, especially in patients requiring critical care, since they can cause dehydration, ketoacidosis and acute kidney injury [55].

\section{USE OF GLP-1RAS IN PATIENTS WITH T2DM AND COVID-19}

Endogenous GLP-1 harbours anti-inflammatory properties $[28,29,59]$. These may be beneficial in patients with sepsis [60]. Hence, GLP-1RAs might attenuate excess inflammation in COVID-19. Liraglutide was shown to activate ACE2 expression in experimental animals; however, it is still uncertain whether this could lead to the facilitation or prevention of the infection and replication of SARS-CoV-2 in patients with T2DM [61]. On the other hand, since SARS-CoV-2 infection leads to increased ROS production [19], which has multiple negative effects on metabolism, cardiovascular system and the lungs, it has to be recalled that liraglutide has the ability to reduce oxidative stress in T2DM [62]. In addition, GLP-1RAs harbour beneficial cardiorenal properties [63], and could represent an ideal treatment option for patients with T2DM and cardiovascular and/ or kidney disease during COVID-19 [64].

In a previously cited multinational retrospective cohort study, using data from a COVID-19 Research Network, GLP-1RAs users were hallmarked by the significant reductions in mortality (47\%) and in hospital admissions (40\%), including a reduction in respiratory complications (46\%) [35]. A previously mentioned observational study from the National COVID Cohort Collaborative (N3C) group demonstrated that both GLP1-RAs and SGLT2i use were associated with lower 60-day mortality compared to DPP4i use [48]. Additionally, a population-based study using data from nationwide registries revealed that GLP-1RAs users had similar 30-day mortality to SGLT2i users, and that users of both of these drug classes had lower 30-day mortality than DPP4i users [47], while the risks of hospital admission, ICU admission and mechanical ventilation were overall similar in GLP-1RAs and DPP4i users in comparison to SGLT2i users [47].

The previously mentioned multicentre observational study encompassing very old patients with T2DM and COVID-19 in Spain revealed no association between preadmission use of GLP-1RAs and in-hospital mortality [34]. Additionally, in a UK multicentre retrospective cohort study there was no association between usage of different antidiabetic medications (including GLP-1RAs, DPP4i, insulin, metformin, sulfonylurea and SGLT2i) and the risk of death and/or ICU admission within 30 days of COVID-19 diagnosis [37]. Finally, in an Italian retrospective observational study, only metformin usage was associated with lower case fatality, while there was no association between usage of various antidiabetic medications (GLP1RAs, DPP4i, metformin, pioglitazone, insulin, sulfonylurea/glinides and SGLT2i) and the risk of either COVID-19 or case fatality [38].

A recently published meta-analysis analysed the impact of preadmission use of GLP-1RAs on mortality outcomes of COVID-19 among patients with DM [65]. Very interestingly, the authors concluded that preadmission usage of GLP-1RAs was associated with reduction in mortality rate in patients with DM and COVID19 independently of age, gender, hypertension, cardiovascular disease and the use of metformin and insulin [65]. Further studies investigating the role of GLP-1RAs in COVID-19 are already planned or undergoing [e.g. NCT04615871]. Although lots of hope has been invested in the beneficial role of GLP-1RAs among patients with T2DM and COVID-19 [66], considering the well-established and favourable metabolic and cardiorenal properties $[56,63]$, their initiation 
Table 1 Summary of studies evaluating the use of novel antidiabetic agents in patients with T2DM and COVID-19

\begin{tabular}{|c|c|c|c|c|}
\hline Authors & Study design & Primary outcome & $\begin{array}{l}N \text { of } \\
\text { patients }\end{array}$ & Main results \\
\hline \multicolumn{5}{|l|}{ DPP4i } \\
\hline $\begin{array}{l}\text { Solerte } \\
{[32]}\end{array}$ & $\begin{array}{l}\text { Multicentre, case-control, } \\
\text { retrospective, observational } \\
\text { study; adding sitagliptin to } \\
\text { standard of care }\end{array}$ & $\begin{array}{l}\text { Discharge from hospital, } \\
\text { improvement of clinical } \\
\text { outcomes and mortality }\end{array}$ & 338 & $\begin{array}{l}\text { Positive } \\
\text { Reduced mortality, } \\
\text { improvement in clinical } \\
\text { outcomes, greater number of } \\
\text { hospital discharges with } \\
\text { sitagliptin }\end{array}$ \\
\hline $\begin{array}{l}\text { Mirani } \\
{[33]}\end{array}$ & $\begin{array}{l}\text { Single-centre, case series; } \\
\text { evaluating the use of DPP } 4 \mathrm{i}\end{array}$ & Mortality & 90 & $\begin{array}{l}\text { Positive } \\
\text { Lower risk of mortality with } \\
\text { DPP } 4 \mathrm{i}\end{array}$ \\
\hline $\begin{array}{l}\text { Ramos- } \\
\text { Rincón } \\
{[34]}\end{array}$ & $\begin{array}{l}\text { Nationwide, multicentre } \\
\text { observational study; } \\
\text { evaluating use of several } \\
\text { antidiabetic drugs, including } \\
\text { DPP4i, GLP-1RAs and } \\
\text { SGLT2i }\end{array}$ & Mortality & 790 & $\begin{array}{l}\text { Positive } \\
\text { DPP4i were independent } \\
\text { protectors for mortality; } \\
\text { metformin, insulin, GLP- } \\
\text { 1RAs and SGLT2i had a } \\
\text { neutral effect on mortality }\end{array}$ \\
\hline $\begin{array}{l}\text { Nyland } \\
{[35]}\end{array}$ & $\begin{array}{l}\text { Multinational retrospective } \\
\text { cohort study; evaluating use } \\
\text { of pioglitazone, GLP-1RAs } \\
\text { and DPP4i in comparison to } \\
\text { no use of such therapies }\end{array}$ & Mortality & 7769 & $\begin{array}{l}\text { Positive } \\
\text { Significant reductions in } \\
\text { mortality among users of } \\
\text { pioglitazone, GLP-1RAs and } \\
\text { DPP4i in comparison to } \\
\text { non-users of pioglitazone, } \\
\text { GLP-1RAs or DPP4i }\end{array}$ \\
\hline $\begin{array}{l}\text { Sainsbury } \\
{[36]}\end{array}$ & $\begin{array}{l}\text { Propensity score-matched } \\
\text { cohort study, evaluating } \\
\text { SGLT2i use in comparison } \\
\text { to DPP4i }\end{array}$ & $\begin{array}{l}\text { Confirmed or clinically } \\
\text { suspected COVID-19 }\end{array}$ & 24,865 & $\begin{array}{l}\text { Neutral } \\
\text { Similar risk of confirmed or } \\
\text { clinically suspected COVID- } \\
19\end{array}$ \\
\hline $\begin{array}{l}\text { Izzi- } \\
\text { Engbeaya } \\
{[37]}\end{array}$ & $\begin{array}{l}\text { Multicentre retrospective } \\
\text { cohort study; evaluating use } \\
\text { of insulin, GLP-1RAs, } \\
\text { metformin, sulfonylurea, } \\
\text { SGLT2i and DPP4i }\end{array}$ & $\begin{array}{l}\text { Death and/or ICU admission } \\
\text { within } 30 \text { days of COVID- } \\
19 \text { diagnosis }\end{array}$ & 278 & $\begin{array}{l}\text { Neutral } \\
\text { No association between } \\
\text { insulin, GLP-1RAs, } \\
\text { metformin, sulfonylurea, } \\
\text { SGLT2i and DPP4i use and } \\
\text { the risk of death and/or ICU } \\
\text { admission within } 30 \text { days of } \\
\text { COVID-19 }\end{array}$ \\
\hline $\begin{array}{l}\text { Silverii } \\
{[38]}\end{array}$ & $\begin{array}{l}\text { Retrospective observational } \\
\text { study; evaluating use of } \\
\text { metformin, pioglitazone, } \\
\text { insulin, sulfonylurea/ } \\
\text { glinides, DPP4i, SGLT2i } \\
\text { and GLP-1RAs }\end{array}$ & $\begin{array}{l}\text { COVID-19 prevalence and } \\
\text { case fatality }\end{array}$ & 159 & $\begin{array}{l}\text { Neutral } \\
\text { No association with COVID- } \\
19 \text { prevalence; metformin use } \\
\text { associated with a lower case } \\
\text { fatality }\end{array}$ \\
\hline
\end{tabular}


Table 1 continued

\begin{tabular}{|c|c|c|c|c|}
\hline Authors & Study design & Primary outcome & $\begin{array}{l}N \text { of } \\
\text { patients }\end{array}$ & Main results \\
\hline Orioli [39] & $\begin{array}{l}\text { Retrospective single-centre } \\
\text { cohort study; evaluating use } \\
\text { of different antidiabetic } \\
\text { medications }\end{array}$ & In-hospital mortality & 73 & $\begin{array}{l}\text { Neutral } \\
\text { Non-survivors were less often } \\
\text { treated with metformin prior } \\
\text { to admission in comparison } \\
\text { to survivors }\end{array}$ \\
\hline $\begin{array}{l}\text { Wargny } \\
{[40]}\end{array}$ & $\begin{array}{l}\text { Update on the results of } \\
\text { nationwide CORONADO } \\
\text { study; evaluating use of } \\
\text { metformin, sulfonylurea/ } \\
\text { glinides, DPP4i, GLP-1RAs } \\
\text { and insulin }\end{array}$ & $\begin{array}{l}\text { Hospital discharge and death } \\
\text { within } 28 \text { days }\end{array}$ & 2796 & $\begin{array}{l}\text { Neutral } \\
\text { Routine metformin therapy } \\
\text { was one of the predictors of } \\
\text { discharge on day } 28 \text { and } \\
\text { negatively associated with } \\
\text { death within } 28 \text { days; routine } \\
\text { insulin therapy was associated } \\
\text { with greater risk of death } \\
\text { within } 28 \text { days }\end{array}$ \\
\hline Noh $[41]$ & $\begin{array}{l}\text { Nationwide cohort study; } \\
\text { evaluating use of DPP4i }\end{array}$ & All-cause mortality & 586 & $\begin{array}{l}\text { Negative } \\
\text { DPP4i had no effect on all- } \\
\text { cause mortality }\end{array}$ \\
\hline Fadini $[42]$ & $\begin{array}{l}\text { Case-control study; evaluating } \\
\text { use of DPP4i }\end{array}$ & Risk of hospitalisation & 85 & $\begin{array}{l}\text { Negative } \\
\text { DPP4i had no effect on the } \\
\text { risk of hospitalisation }\end{array}$ \\
\hline $\begin{array}{l}\text { Strollo } \\
{[43]}\end{array}$ & $\begin{array}{l}\text { Review of medical charts; } \\
\text { evaluating geographical } \\
\text { differences in DPP4i use }\end{array}$ & $\begin{array}{l}\text { Prevalence of diabetes among } \\
\text { COVID-19 deaths }\end{array}$ & 3351 & $\begin{array}{l}\text { Negative } \\
\text { Geographical differences did } \\
\text { not correlate with diabetes } \\
\text { prevalence among COVID- } \\
19 \text { deaths }\end{array}$ \\
\hline $\begin{array}{l}\text { Roussel } \\
{[44]}\end{array}$ & $\begin{array}{l}\text { Secondary analysis of the } \\
\text { nationwide CORONADO } \\
\text { study; evaluating DPP4i use }\end{array}$ & $\begin{array}{l}\text { Tracheal intubation for } \\
\text { mechanical ventilation and } \\
\text { death within } 7 \text { days of } \\
\text { admission }\end{array}$ & 2449 & $\begin{array}{l}\text { Negative } \\
\text { DPP4i had no effect on } \\
\text { tracheal intubation for } \\
\text { mechanical ventilation and } \\
\text { death within } 7 \text { days of } \\
\text { admission occurred at similar } \\
\text { rates }\end{array}$ \\
\hline Zhou [45] & $\begin{array}{l}\text { Multicentre retrospective } \\
\text { analysis; evaluating DPP4i } \\
\text { use }\end{array}$ & 28-day all-cause mortality & 1257 & $\begin{array}{l}\text { Negative } \\
\text { DPP4i had no effect on all- } \\
\text { cause mortality }\end{array}$ \\
\hline Dalan [46] & $\begin{array}{l}\text { Retrospective, observational } \\
\text { cohort study; evaluating use } \\
\text { of DPP4i, SGLT2i and } \\
\text { sulfonylureas }\end{array}$ & $\begin{array}{l}\text { Hypoxia, ICU admission, } \\
\text { mechanical ventilation or } \\
\text { death }\end{array}$ & 76 & $\begin{array}{l}\text { Negative } \\
\text { DPP4i associated with higher } \\
\text { risk of ICU admission and } \\
\text { mechanical ventilation, } \\
\text { SGLT2i associated with } \\
\text { lower risk of mechanical } \\
\text { ventilation }\end{array}$ \\
\hline
\end{tabular}


Table 1 continued

\begin{tabular}{|c|c|c|c|c|}
\hline Authors & Study design & Primary outcome & $\begin{array}{l}N \text { of } \\
\text { patients }\end{array}$ & Main results \\
\hline $\begin{array}{l}\text { Israelsen } \\
{[47]}\end{array}$ & $\begin{array}{l}\text { Population-based cohort study; } \\
\text { evaluating use of SGLT2i in } \\
\text { comparison to DPP4i and } \\
\text { GLP-1RAs }\end{array}$ & $\begin{array}{c}\text { Death within } 30 \text { days after a } \\
\text { positive SARS CoV-2 test }\end{array}$ & 996 & $\begin{array}{l}\text { Negative } \\
\text { Higher 30-day mortality } \\
\text { compared to SGLT2i }\end{array}$ \\
\hline $\begin{array}{l}\text { Kahkoska } \\
{[48]}\end{array}$ & $\begin{array}{l}\text { National observational study, } \\
\text { evaluating use of GLP-1RAs, } \\
\text { SGLT2i and DPP4i }\end{array}$ & 60-day mortality & 12,446 & $\begin{array}{l}\text { Negative } \\
\text { GLP1-RAs and SGLT2i use } \\
\text { both associated with lower } \\
\text { 60-day mortality in } \\
\text { comparison to DPP4i use }\end{array}$ \\
\hline \multicolumn{5}{|l|}{ SGLT2i } \\
\hline Dalan [46] & $\begin{array}{l}\text { Retrospective, observational } \\
\text { cohort study; evaluating use } \\
\text { of DPP4i, SGLT2i and } \\
\text { sulfonylureas }\end{array}$ & $\begin{array}{l}\text { Hypoxia, ICU admission, } \\
\text { mechanical ventilation or } \\
\text { death }\end{array}$ & 76 & $\begin{array}{l}\text { Positive } \\
\text { SGLT2i associated with lower } \\
\text { risk of mechanical } \\
\text { ventilation; DPP4i associated } \\
\text { with higher risk of ICU } \\
\text { admission and mechanical } \\
\text { ventilation }\end{array}$ \\
\hline $\begin{array}{l}\text { Israelsen } \\
{[47]}\end{array}$ & $\begin{array}{l}\text { Population-based cohort study; } \\
\text { evaluating use of SGLT2i in } \\
\text { comparison to DPP4i and } \\
\text { GLP-1RAs }\end{array}$ & $\begin{array}{c}\text { Death within } 30 \text { days after a } \\
\text { positive SARS CoV-2 test }\end{array}$ & 996 & $\begin{array}{l}\text { Positive vs. DPP4i } \\
\text { Neutral vs. GLP-1RAs } \\
\text { Similar 30-day mortality } \\
\text { compared to GLP-1RAs } \\
\text { users and lower 30-day } \\
\text { mortality compared to } \\
\text { DPP4i }\end{array}$ \\
\hline $\begin{array}{l}\text { Kahkoska } \\
{[48]}\end{array}$ & $\begin{array}{l}\text { National observational study, } \\
\text { evaluating use of GLP-1RAs, } \\
\text { SGLT2i and DPP4i }\end{array}$ & 60-day mortality & 12,446 & $\begin{array}{l}\text { Positive } \\
\text { GLP1-RAs and SGLT2i use } \\
\text { both associated with lower } \\
\text { 60-day mortality in } \\
\text { comparison to DPP4i use }\end{array}$ \\
\hline $\begin{array}{l}\text { Ramos- } \\
\text { Rincón } \\
{[34]}\end{array}$ & $\begin{array}{l}\text { Nationwide, multicentre } \\
\text { observational study; } \\
\text { evaluating use of several } \\
\text { antidiabetic drugs, including } \\
\text { DPP4i, GLP-1RAs and } \\
\text { SGLT2i }\end{array}$ & Mortality & 790 & $\begin{array}{l}\text { Neutral } \\
\text { DPP4i were independent } \\
\text { protectors for mortality; } \\
\text { metformin, insulin, GLP- } \\
\text { 1RAs and SGLT2i had a } \\
\text { neutral effect on mortality }\end{array}$ \\
\hline $\begin{array}{l}\text { Sainsbury } \\
{[36]}\end{array}$ & $\begin{array}{l}\text { Propensity score-matched } \\
\text { cohort study, evaluating } \\
\text { SGLT2i use in comparison } \\
\text { to DPP4i }\end{array}$ & $\begin{array}{l}\text { Confirmed or clinically } \\
\text { suspected COVID-19 }\end{array}$ & 24,865 & $\begin{array}{l}\text { Neutral } \\
\text { Similar risk of confirmed or } \\
\text { clinically suspected COVID- } \\
19\end{array}$ \\
\hline
\end{tabular}


Table 1 continued

\begin{tabular}{|c|c|c|c|c|}
\hline Authors & Study design & Primary outcome & $\begin{array}{l}N \text { of } \\
\text { patients }\end{array}$ & Main results \\
\hline $\begin{array}{l}\text { Izzi- } \\
\text { Engbeaya } \\
{[37]}\end{array}$ & $\begin{array}{l}\text { Multicentre retrospective } \\
\text { cohort study; evaluating use } \\
\text { of insulin, GLP-1RAs, } \\
\text { metformin, sulfonylurea, } \\
\text { SGLT2i and DPP4i }\end{array}$ & $\begin{array}{l}\text { Death and/or ICU admission } \\
\text { within } 30 \text { days of COVID- } \\
19 \text { diagnosis }\end{array}$ & 278 & $\begin{array}{l}\text { Neutral } \\
\text { No association between } \\
\text { insulin, GLP-1RAs, } \\
\text { metformin, sulfonylurea, } \\
\text { SGLT2i and DPP4i use and } \\
\text { the risk of death and/or ICU } \\
\text { admission within } 30 \text { days of } \\
\text { COVID-19 }\end{array}$ \\
\hline $\begin{array}{l}\text { Silverii } \\
{[38]}\end{array}$ & $\begin{array}{l}\text { Retrospective observational } \\
\text { study; evaluating use of } \\
\text { metformin, pioglitazone, } \\
\text { insulin, sulfonylurea/ } \\
\text { glinides, DPP4i, SGLT2i } \\
\text { and GLP-1RAs }\end{array}$ & $\begin{array}{l}\text { COVID-19 prevalence and } \\
\text { case fatality }\end{array}$ & 159 & $\begin{array}{l}\text { Neutral } \\
\text { No association with COVID- } \\
19 \text { prevalence; metformin use } \\
\text { associated with a lower case } \\
\text { fatality }\end{array}$ \\
\hline Orioli [39] & $\begin{array}{l}\text { Retrospective single-centre } \\
\text { cohort study; evaluating use } \\
\text { of different antidiabetic } \\
\text { medications }\end{array}$ & In-hospital mortality & 73 & $\begin{array}{l}\text { Neutral } \\
\text { Non-survivors were less often } \\
\text { treated with metformin prior } \\
\text { to admission in comparison } \\
\text { to survivors }\end{array}$ \\
\hline $\begin{array}{l}\text { Kosiborod } \\
{[57]}\end{array}$ & $\begin{array}{l}\text { Randomised, double-blind, } \\
\text { placebo-controlled trial; } \\
\text { evaluating use of } \\
\text { dapagliflozin in comparison } \\
\text { to placebo among high-risk } \\
\text { but not critically ill patients } \\
\text { with COVID-19 }\end{array}$ & $\begin{array}{l}\text { The outcome of prevention } \\
\text { (time to new or worsened } \\
\text { organ dysfunction or death) } \\
\text { and the hierarchial } \\
\text { composite outcome of } \\
\text { recovery (change in clinical } \\
\text { status by day } 30 \text { ) }\end{array}$ & 1250 & $\begin{array}{l}\text { Negative } \\
\text { No significant impact on } \\
\text { prevention of organ } \\
\text { dysfunction, reduction in all- } \\
\text { cause mortality and } \\
\text { improvement in the clinical } \\
\text { status (ranging from early } \\
\text { recovery to death) at } 30 \text { days }\end{array}$ \\
\hline \multicolumn{5}{|l|}{ GLP1-RAs } \\
\hline $\begin{array}{l}\text { Nyland } \\
{[35]}\end{array}$ & $\begin{array}{l}\text { Multinational retrospective } \\
\text { cohort study; evaluating use } \\
\text { of pioglitazone, GLP-1RAs } \\
\text { and DPP4i in comparison to } \\
\text { no use of such therapies }\end{array}$ & Mortality & 7769 & $\begin{array}{l}\text { Positive } \\
\text { Significant reductions in } \\
\text { mortality among users of } \\
\text { pioglitazone, GLP-1RAs and } \\
\text { DPP4i in comparison to } \\
\text { non-users of pioglitazone, } \\
\text { GLP-1RAs or DPP4i }\end{array}$ \\
\hline $\begin{array}{l}\text { Kahkoska } \\
{[48]}\end{array}$ & $\begin{array}{l}\text { National observational study, } \\
\text { evaluating use of GLP-1RAs, } \\
\text { SGLT2i and DPP4i }\end{array}$ & 60-day mortality & 12,446 & $\begin{array}{l}\text { Positive } \\
\text { GLP1-RAs and SGLT2i use } \\
\text { both associated with lower } \\
\text { 60-day mortality in } \\
\text { comparison to DPP4i use }\end{array}$ \\
\hline
\end{tabular}


Table 1 continued

\begin{tabular}{|c|c|c|c|c|}
\hline Authors & Study design & Primary outcome & $\begin{array}{l}N \text { of } \\
\text { patients }\end{array}$ & Main results \\
\hline $\begin{array}{l}\text { Israelsen } \\
{[47]}\end{array}$ & $\begin{array}{l}\text { Population-based cohort study; } \\
\text { evaluating use of SGLT2i in } \\
\text { comparison to DPP4i and } \\
\text { GLP-1RAs }\end{array}$ & $\begin{array}{c}\text { Death within } 30 \text { days after a } \\
\text { positive SARS CoV-2 test }\end{array}$ & 996 & $\begin{array}{l}\text { Positive vs. DPP4i } \\
\text { Neutral vs. } S G L T 2 i \\
\text { GLP-1RAs had similar 30-day } \\
\text { mortality compared to } \\
\text { SGLT2i users and lower } \\
\text { 30-day mortality compared } \\
\text { to DPP4i }\end{array}$ \\
\hline $\begin{array}{l}\text { Ramos- } \\
\text { Rincón } \\
{[34]}\end{array}$ & $\begin{array}{l}\text { Nationwide, multicentre } \\
\text { observational study; } \\
\text { evaluating use of several } \\
\text { antidiabetic drugs, including } \\
\text { DPP4i, GLP-1RAs and } \\
\text { SGLT2i }\end{array}$ & Mortality & 790 & $\begin{array}{l}\text { Neutral } \\
\text { DPP4i were independent } \\
\text { protectors for mortality; } \\
\text { metformin, insulin, GLP- } \\
\text { 1RAs and SGLT2i had a } \\
\text { neutral effect on mortality }\end{array}$ \\
\hline $\begin{array}{l}\text { Izzi- } \\
\text { Engbeaya } \\
{[37]}\end{array}$ & $\begin{array}{l}\text { Multicentre retrospective } \\
\text { cohort study; evaluating use } \\
\text { of insulin, GLP-1RAs, } \\
\text { metformin, sulfonylurea, } \\
\text { SGLT2i and DPP4i }\end{array}$ & $\begin{array}{l}\text { Death and/or ICU admission } \\
\text { within } 30 \text { days of COVID- } \\
19 \text { diagnosis }\end{array}$ & 278 & $\begin{array}{l}\text { Neutral } \\
\text { No association between } \\
\text { insulin, GLP-1RAs, } \\
\text { metformin, sulfonylurea, } \\
\text { SGLT2i and DPP4i use and } \\
\text { the risk of death and/or ICU } \\
\text { admission within } 30 \text { days of } \\
\text { COVID-19 }\end{array}$ \\
\hline $\begin{array}{l}\text { Silverii } \\
{[38]}\end{array}$ & $\begin{array}{l}\text { Retrospective observational } \\
\text { study; evaluating use of } \\
\text { metformin, pioglitazone, } \\
\text { insulin, sulfonylurea/ } \\
\text { glinides, DPP4i, SGLT2i } \\
\text { and GLP-1RAs }\end{array}$ & $\begin{array}{l}\text { COVID-19 prevalence and } \\
\text { case fatality }\end{array}$ & 159 & $\begin{array}{l}\text { Neutral } \\
\text { No association with COVID- } \\
19 \text { prevalence; metformin use } \\
\text { associated with a lower case } \\
\text { fatality }\end{array}$ \\
\hline
\end{tabular}

COVID-19 coronavirus disease 2019, SARS-CoV-2 severe acute respiratory syndrome coronavirus 2, DPP4i dipeptidyl peptidase 4 inhibitors, GLP-1RAs glucagon-like peptide 1 receptor agonists, $S G L T 2 i$ sodium-glucose co-transporter 2 inhibitors, CORONADO coronavirus SARS-CoV-2 and diabetes outcomes, ICU intensive care unit

and maintenance in critically ill patients were not fully recommended, since they require slow dose uptitration, need time to become effective and are often associated with transient gastrointestinal side effects such as nausea and vomiting [19]. Yet, GLP-1RAs seem to represent appropriate treatment for non-critically ill patients with T2DM, and a molecular mechanism by which GLP1-RAs seem to interact with SARS-CoV-2 activity has been recently discussed [67]; in addition, GLP1-RAs are able to reduce inflammatory cytokines, which have a critical role in both diabetes and cardiovascular diseases [68], therefore reducing the cytokine storm produced by SARS-CoV-2 [69]. 


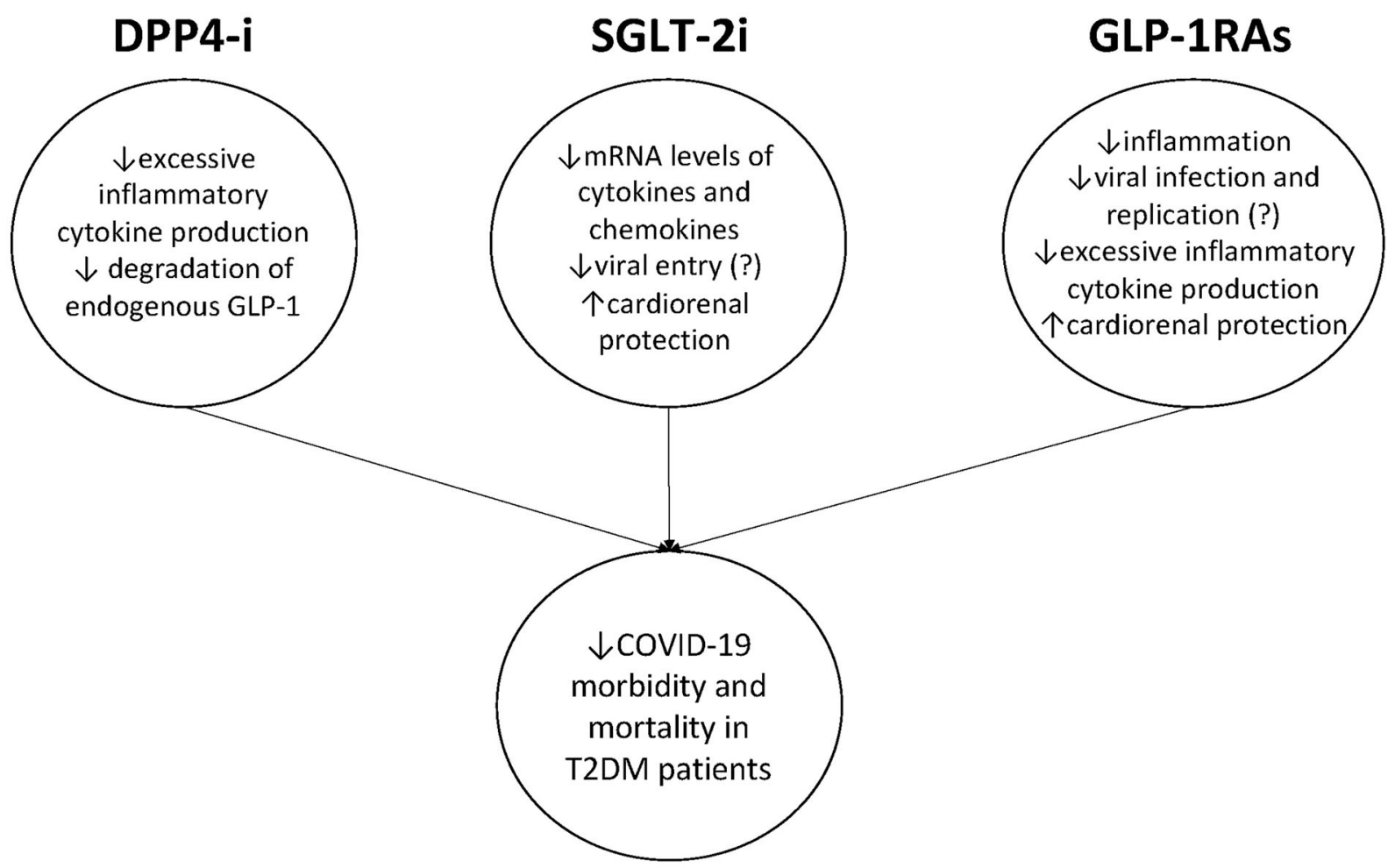

Fig. 1 Potential mechanisms of beneficial effects of novel antidiabetic agents on COVID-19 morbidity and mortality among patients with T2DM

\section{CONCLUSIONS}

Appropriate treatment of people with T2DM and COVID-19 is a top priority considering the unfavourable outcomes in this vulnerable population. In this regard, the use of novel antidiabetic agents has generated considerable interest. However, studies conducted thus far either show inconsistent results (DPP4i) or are sparse in number (SGLT2i and GLP-1RAs) (Table 1). Potential mechanisms of beneficial effects of novel antidiabetic agents on COVID19 outcome are shown in Fig. 1. Interestingly, recent meta-analysis performed to clarify effects of antidiabetic agents on COVID-19 in patients with DM showed that metformin use was associated with lower mortality and poor composite outcomes [70]. Sulfonylurea/glinides use was associated with lower mortality, while there was no significant association for DPP4i, SGLT2i and GLP-1RAs [70].

On top of that, a nationwide observational cohort study from England, analysing 13,479
COVID-19 related deaths in patients with T2DM, showed that adjusted hazard ratios associated with different antidiabetic drugs were 0.75 for meglitinides, 0.77 for metformin, 0.82 for SGLT2i, 0.94 for thiazolidinediones, 0.94 for sulfonylureas, 0.94 for GLP-1RAs, 1.07 for DPP4i, 1.26 for $\alpha$-glucosidase inhibitors and 1.42 for insulin [71]. This data suggests that some of the traditional antidiabetic drugs, such as metformin, might have beneficial effects on COVID-19 outcomes among patients with T2DM [72], although there are also totally opposite data [73].

In conclusion, the use of novel antidiabetic agents DPP4i, SGLT2i and GLP-1RAs in subjects with T2DM and COVID-19 have shown overall some beneficial effects but with different results for different studies. This may be linked to the large discrepancy in many critical aspects among the different studies, such as the inclusion and exclusion criteria, the type of outcome evaluated as well as the presence of concomitant comorbidities. Relevant studies either show 
inconsistent results (as for DPP4i) or are still too few (as for SGLT2i and GLP-1RAs) to be able to make definitive conclusions. Nevertheless, it is hoped that future trials will be helpful in clarifying the risk-benefit ratio of specific antidiabetic agents on COVID-19 outcomes.

\section{ACKNOWLEDGEMENTS}

Funding. No funding or sponsorship was received for this study or publication of this article.

Authorship. All named authors meet the International Committee of Medical Journal Editors (ICMJE) criteria for authorship for this article, take responsibility for the integrity of the work as a whole, and have given their approval for this version to be published.

Authors' Contributions. Djordje S. Popovic has analysed the literature and wrote the manuscript; Nikolaos Papanas has analysed the literature and wrote the manuscript; Anca Pantea Stoian has analysed the literature, reviewed and edited the manuscript; Ali A. Rizvi has reviewed and edited the manuscript; Andrej Janez has reviewed and edited the manuscript; Manfredi Rizzo did the conceptualisation of the study and also reviewed, edited and finalised the manuscript.

Disclosures. This manuscript was written independently and the authors did not receive financial or professional help for its preparation. Djordje S. Popovic declares associations that might represent a conflict of interest with the following companies: Abbott, Alkaloid, AstraZeneca, Boehringer Ingelheim, BerlinChemie, Eli Lilly, Galenika, Krka, Merck, Novo Nordisk, PharmaSwiss, Sanofi-Aventis, Servier, and Worwag Pharma. Nikolaos Papanas has been an advisory board member of TrigoCare International, Abbott, AstraZeneca, Elpen, MSD, Novartis, Novo Nordisk, Sanofi-Aventis, and Takeda; has participated in sponsored studies by Eli Lilly, MSD, Novo Nordisk, Novartis, and Sanofi-Aventis; received honoraria as a speaker for AstraZeneca, Boehringer Ingelheim, Eli Lilly, Elpen, Galenica, MSD, Mylan, Novartis, Novo Nordisk, Pfizer, Sanofi-Aventis, Takeda, and Vianex; and attended conferences sponsored by TrigoCare International, AstraZeneca, Boehringer Ingelheim, Eli Lilly, Novartis, Novo Nordisk, Pfizer, and Sanofi-Aventis. Anca Pantea Stoian is currently Vice President of Romanian National Diabetes Committee, and she has given lectures, received honoraria and research support, and participated in conferences, advisory boards and clinical trials sponsored by many companies including Amgen, AstraZeneca, Boehringer Ingelheim, Medtronic, Eli Lilly, Merck, MSD, Novo Nordisk, Novartis, Roche Diagnostics, Servier, and Sanofi. Ali A. Rizvi has nothing to disclose. Since the completion of this work, A. Rizvi has changed affiliation to the Department of Medicine, University of Central Florida College of Medicine, Orlando, Florida, USA. Andrej Janez discloses consultancies and speaker bureaus for AstraZeneca, Boehringer Ingelheim, Eli Lilly, Merck Sharp \& Dohme (MSD), Novo Nordisk, Sanofi, and Medtronic. Manfredi Rizzo is a full-time Professor of Internal Medicine at the University of Palermo, Italy, Editorial Board member of Diabetes Therapy and currently Medical Director in Novo Nordisk Eastern Europe; he has given lectures, received honoraria and research support, and participated in conferences, advisory boards, and clinical trials sponsored by many pharmaceutical companies including Amgen, AstraZeneca, Boehringer Ingelheim, Kowa, Eli Lilly, Meda, Mylan, Merck Sharp \& Dohme, Novo Nordisk, Novartis, Roche Diagnostics, Sanofi, and Servier. None of the aforementioned pharmaceutical companies had any role in this article, which has been written independently, without any financial or professional help, and reflects only the opinion of the authors, without any role of the industry.

Compliance with Ethics Guidelines. This article is based on previously conducted studies and does not contain any new studies with human participants or animals performed by any of the authors. 
Data Availability. Data sharing is not applicable to this article as no datasets were generated or analysed during the current study.

Open Access. This article is licensed under a Creative Commons Attribution-NonCommercial 4.0 International License, which permits any non-commercial use, sharing, adaptation, distribution and reproduction in any medium or format, as long as you give appropriate credit to the original author(s) and the source, provide a link to the Creative Commons licence, and indicate if changes were made. The images or other third party material in this article are included in the article's Creative Commons licence, unless indicated otherwise in a credit line to the material. If material is not included in the article's Creative Commons licence and your intended use is not permitted by statutory regulation or exceeds the permitted use, you will need to obtain permission directly from the copyright holder. To view a copy of this licence, visit http://creativecommons.org/licenses/bync/4.0/.

\section{REFERENCES}

1. Zhu N, Zhang D, Wang W, et al. A novel coronavirus from patients with pneumonia in China, 2019. N Engl J Med. 2020;382:727-33.

2. Chen N, Zhou M, Dong X, et al. Epidemiological and clinical characteristics of 99 cases of 2019 novel coronavirus pneumonia in Wuhan, China: a descriptive study. Lancet. 2020;395:507-13.

3. Li Q, Guan $\mathrm{X}, \mathrm{Wu} \mathrm{P}$, et al. Early transmission dynamics in Wuhan, China, of novel coronavirusinfected pneumonia. N Engl J Med. 2020;382: 1199-207.

4. Huang C, Wang Y, Li X, et al. Clinical features of patients infected with 2019 novel coronavirus in Wuhan. China Lancet. 2020;395:497-506.

5. Walls AC, Park YJ, Tortorici MA, Wall A, McGuire AT, Veesler D. Structure, function, and antigenicity of the SARS-CoV-2 spike glycoprotein. Cell. 2020;181:281-292.e6.
6. Zhang H, Penninger JM, Li Y, Zhong N, Slutsky AS. Angiotensin-converting enzyme 2 (ACE2) as a SARS-CoV-2 receptor: molecular mechanisms and potential therapeutic target. Intensive Care Med. 2020;46:586-90.

7. Wu Z, McGoogan JM. Characteristics of and important lessons from the coronavirus disease 2019 (COVID-19) outbreak in China: summary of a report of 72314 cases from the Chinese Center for Disease Control and Prevention. JAMA. 2020;323: 1239-42.

8. Grasselli G, Zangrillo A, Zanella A, et al. Baseline characteristics and outcomes of 1591 patients infected with SARS-CoV-2 admitted to ICUs of the Lombardy Region. Italy JAMA. 2020;323:1574-81.

9. Goyal P, Choi JJ, Pinheiro LC, et al. Clinical characteristics of Covid-19 in New York City. N Engl J Med. 2020;382:2372-4.

10. Pantea Stoian A, Pricop-Jeckstadt M, Pana A, et al. Death by SARS-CoV 2: a Romanian COVID-19 multi-centre comorbidity study. Sci Rep. 2020;10: 21613.

11. Stoian AP, Banerjee Y, Rizvi AA, Rizzo M. Diabetes and the COVID-19 pandemic: how insights from recent experience might guide future management. Metab Syndr Relat Disord. 2020;18:173-5.

12. Codo AC, Davanzo GG, Monteiro LB, et al. Elevated glucose levels favor SARS-CoV-2 infection and monocyte response through a HIF-1 $\alpha /$ glycolysisdependent axis. Cell Metab. 2020;32:437-446.e5.

13. Zhu L, She ZG, Cheng X, et al. Association of blood glucose control and outcomes in patients with COVID-19 and pre-existing type 2 diabetes. Cell Metab. 2020;31:1068-1077.e3.

14. Critchley JA, Carey IM, Harris T, DeWilde S, Hosking FJ, Cook DG. Glycemic control and risk of infections among people with type 1 or type 2 diabetes in a large primary care cohort study. Diabetes Care. 2018;41:2127-35.

15. Šestan M, Marinović S, Kavazović I, et al. Virus-induced interferon- $\gamma$ causes insulin resistance in skeletal muscle and derails glycemic control in obesity. Immunity. 2018;49:164-177.e6.

16. Groop LC, Bonadonna RC, DelPrato S, et al. Glucose and free fatty acid metabolism in non-insulindependent diabetes mellitus. Evidence for multiple sites of insulin resistance. J Clin Invest. 1989;84: 205-13.

17. Cheema AK, Kaur P, Fadel A, Younes N, Zirie M, Rizk NM. Integrated datasets of proteomic and metabolomic biomarkers to predict its impacts on 
comorbidities of type 2 diabetes mellitus. Diabetes Metab Syndr Obes. 2020;13:2409-31.

18. Cariou B, Hadjadj S, Wargny M, et al. Phenotypic characteristics and prognosis of inpatients with COVID-19 and diabetes: the CORONADO study. Diabetologia. 2020;63:1500-15.

19. Lim S, Bae JH, Kwon HS, Nauck MA. COVID-19 and diabetes mellitus: from pathophysiology to clinical management. Nat Rev Endocrinol. 2021;17:11-30.

20. Wang L, Liang J, Leung PS. The ACE2/Ang-(1-7)/ Mas axis regulates the development of pancreatic endocrine cells in mouse embryos. PLoS ONE. 2015;10: e0128216.

21. Yang JK, Lin SS, Ji XJ, Guo LM. Binding of SARS coronavirus to its receptor damages islets and causes acute diabetes. Acta Diabetol. 2010;47:193-9.

22. Tang N, Li D, Wang X, Sun Z. Abnormal coagulation parameters are associated with poor prognosis in patients with novel coronavirus pneumonia. J Thromb Haemost. 2020;18:844-7.

23. Rizvi AA, Stoian AP, Lessan N, Rizzo M. Endocrinology in the time of COVID-19: a rapid evolution of knowledge and care. Medicina. 2021;57:805.

24. Hoffmann M, Kleine-Weber H, Schroeder S, et al. SARS-CoV-2 cell entry depends on ACE2 and TMPRSS2 and is blocked by a clinically proven protease inhibitor. Cell. 2020;181:271-280.e8.

25. Millet JK, Jaimes JA, Whittaker GR. Molecular diversity of coronavirus host cell entry receptors. FEMS Microbiol Rev. 2021;45: fuaa057.

26. Iacobellis G. COVID-19 and diabetes: can DPP4 inhibition play a role? Diabetes Res Clin Pract. 2020;162:108125.

27. Maddaloni E, Buzzetti R. Covid-19 and diabetes mellitus: unveiling the interaction of two pandemics. Diabetes Metab Res Rev. 2020;36: e33213321.

28. Lee YS, Park MS, Choung JS, et al. Glucagon-like peptide- 1 inhibits adipose tissue macrophage infiltration and inflammation in an obese mouse model of diabetes. Diabetologia. 2012;55:2456-68.

29. Lee YS, Jun HS. Anti-inflammatory effects of GLP-1based therapies beyond glucose control. Mediators Inflamm. 2016;2016:3094642.

30. Stengel A, Goebel-Stengel M, Teuffel P, et al. Obese patients have higher circulating protein levels of dipeptidyl peptidase IV. Peptides. 2014;61:75-82.
31. Kirino Y, Sei M, Kawazoe K, Minakuchi K, Sato Y. Plasma dipeptidyl peptidase 4 activity correlates with body mass index and the plasma adiponectin concentration in healthy young people. Endocr J. 2012;59:949-53.

32. Solerte SB, D'Addio F, Trevisan R, et al. Sitagliptin treatment at the time of hospitalization was associated with reduced mortality in patients with type 2 diabetes and COVID-19: a multicenter, casecontrol, retrospective, observational study. Diabetes Care. 2020;43:2999-3006.

33. Mirani M, Favacchio G, Carrone F, et al. Impact of comorbidities and glycemia at admission and dipeptidyl peptidase 4 inhibitors in patients with type 2 diabetes with COVID-19: a case series from an academic hospital in Lombardy, Italy. Diabetes Care. 2020;43:3042-9.

34. Ramos-Rincón JM, Pérez-Belmonte LM, CarrascoSánchez FJ, et al. Cardiometabolic therapy and mortality in very old patients with diabetes hospitalized due to COVID-19. J Gerontol A Biol Sci Med Sci. 2021;76:e102-9.

35. Nyland JE, Raja-Khan NT, Bettermann K, et al. Diabetes, drug treatment and mortality in COVID19: a multinational retrospective cohort study. SSRN J. 2020. https://doi.org/10.2139/ssrn. 3725612 .

36. Sainsbury C, Wang J, Gokhale K, et al. Sodiumglucose co-transporter-2 inhibitors and susceptibility to COVID-19: a population-based retrospective cohort study. Diabetes Obes Metab. 2021;23:263-9.

37. Izzi-Engbeaya C, Distaso W, Amin A, et al. Adverse outcomes in COVID-19 and diabetes: a retrospective cohort study from three London teaching hospitals. BMJ Open Diabetes Res Care. 2021;9: e001858.

38. Silverii GA, Monami M, Cernigliaro A, et al. Are diabetes and its medications risk factors for the development of COVID-19? Data from a population-based study in Sicily. Nutr Metab Cardiovasc Dis. 2021;31:396-8.

39. Orioli L, Servais T, Belkhir L, et al. Clinical characteristics and short-term prognosis of in-patients with diabetes and COVID-19: a retrospective study from an academic center in Belgium. Diabetes Metab Syndr. 2021;15:149-57.

40. Wargny M, Potier L, Gourdy P, et al. Predictors of hospital discharge and mortality in patients with diabetes and COVID-19: updated results from the nationwide CORONADO study. Diabetologia. 2021;64:778-94. 
41. Noh Y, Oh IS, Jeong HE, Filion KB, Yu OHY, Shin JY. Association between DPP-4 inhibitors and COVID19-related outcomes among patients with type 2 diabetes. Diabetes Care. 2021;44:e64-6.

42. Fadini GP, Morieri ML, Longato E, et al. Exposure to dipeptidyl-peptidase- 4 inhibitors and COVID-19 among people with type 2 diabetes: a case-control study. Diabetes Obes Metab. 2020;22:1946-50.

43. Strollo R, Maddaloni E, Dauriz M, Pedone C, Buzzetti R, Pozzilli P. Use of DPP4 inhibitors in Italy does not correlate with diabetes prevalence among COVID-19 deaths. Diabetes Res Clin Pract. $2021 ; 171: 108444$.

44. Roussel R, Darmon P, Pichelin M, et al. Use of dipeptidyl peptidase-4 inhibitors and prognosis of COVID-19 in hospitalized patients with type 2 diabetes: a propensity score analysis from the CORONADO study. Diabetes Obes Metab. 2021;23: 1162-72.

45. Zhou JH, Wu B, Wang WX, et al. No significant association between dipeptidyl peptidase- 4 inhibitors and adverse outcomes of COVID-19. World J Clin Cases. 2020;8:5576-88.

46. Dalan R, Ang LW, Tan WYT, et al. The association of hypertension and diabetes pharmacotherapy with COVID-19 severity and immune signatures: an observational study. Eur Heart J Cardiovasc Pharmacother. 2021;7:e48-51.

47. Israelsen SB, Pottegård $\mathrm{A}$, Sandholdt $\mathrm{H}$, Madsbad $\mathrm{S}$, Thomsen RW, Benfield T. Comparable COVID-19 outcomes with current use of GLP-1 receptor agonists, DPP-4 inhibitors or SGLT-2 inhibitors among patients with diabetes who tested positive for SARSCoV-2. Diabetes Obes Metab. 2021;23:1397-401.

48. Kahkoska AR, Abrahamsen TJ, Alexander GC, et al. Association between glucagon-like peptide 1 receptor agonist and sodium-glucose cotransporter 2 inhibitor use and COVID-19 outcomes. Diabetes Care. 2021;44:1564-72.

49. Pal R, Banerjee M, Mukherjee S, Bhogal RS, Kaur A, Bhadada SK. Dipeptidyl peptidase- 4 inhibitor use and mortality in COVID-19 patients with diabetes mellitus: an updated systematic review and metaanalysis. Ther Adv Endocrinol Metab. 2021;12: 2042018821996482.

50. Yang Y, Cai Z, Zhang J. DPP-4 inhibitors may improve the mortality of coronavirus disease 2019: a meta-analysis. PLoS ONE. 2021;16: e0251916.

51. Maranta F, Cianfanelli L, Rizzo M, Cianflone D. Filling the gap between guidelines and real world in the cardiovascular approach to the diabetic patients: the need for a call to action. Int J Cardiol. 2021;329:205-7.

52. Garvey WT, Van Gaal L, Leiter LA, et al. Effects of canagliflozin versus glimepiride on adipokines and inflammatory biomarkers in type 2 diabetes. Metabolism. 2018;85:32-7.

53. Couselo-Seijas M, Agra-Bermejo RM, Fernández AL, et al. High released lactate by epicardial fat from coronary artery disease patients is reduced by dapagliflozin treatment. Atherosclerosis. 2020;292: 60-9.

54. Filippatos TD, Liontos A, Papakitsou I, Elisaf MS. SGLT2 inhibitors and cardioprotection: a matter of debate and multiple hypotheses. Postgrad Med. 2019;131:82-8.

55. Hahn K, Ejaz AA, Kanbay M, Lanaspa MA, Johnson RJ. Acute kidney injury from SGLT2 inhibitors: potential mechanisms. Nat Rev Nephrol. 2016;12: 711-2.

56. American Diabetes Association. Pharmacologic approaches to glycemic treatment: standards of medical care in diabetes-2021. Diabetes Care. 2021;44(Suppl 1):S111-24.

57. Kosiborod MN, Esterline R, Furtado RHM, et al. Dapagliflozin in patients with cardiometabolic risk factors hospitalised with COVID-19 (DARE-19): a randomised, double-blind, placebo-controlled, phase 3 trial. Lancet Diabetes Endocrinol. 2021;9: 586-94.

58. Lu IN, Kulkarni S, Fisk M, et al. muLTi-Arm Therapeutic study in pre-ICU patients admitted with Covid-19-experimental drugs and mechanisms (TACTIC-E): a structured summary of a study protocol for a randomized controlled trial. Trials. 2020;21:690.

59. Rizzo M, Rizvi AA, Patti AM, et al. Liraglutide improves metabolic parameters and carotid intimamedia thickness in diabetic patients with the metabolic syndrome: an 18-month prospective study. Cardiovasc Diabetol. 2016;15:162.

60. Shah FA, Mahmud H, Gallego-Martin T, Jurczak MJ, O'Donnell CP, McVerry BJ. Therapeutic effects of endogenous incretin hormones and exogenous incretin-based medications in sepsis. J Clin Endocrinol Metab. 2019;104:5274-84.

61. Pang J, Liu M, Ling W, Jin T. Friend or foe? ACE2 inhibitors and GLP-1R agonists in COVID-19 treatment. Obes Med. 2021;22:100312.

62. Rizzo M, Abate N, Chandalia M, et al. Liraglutide reduces oxidative stress and restores heme oxygenase- 1 and ghrelin levels in patients with type 2 
diabetes: a prospective pilot study. J Clin Endocrinol Metab. 2015;100:603-6.

63. Rizzo M, Nikolic D, Patti AM, et al. GLP-1 receptor agonists and reduction of cardiometabolic risk: potential underlying mechanisms. Biochim Biophys Acta Mol Basis Dis. 2018;1864:2814-21.

64. Ceriello A, Stoian AP, Rizzo M. COVID-19 and diabetes management: what should be considered? Diabetes Res Clin Pract. 2020;163:108151.

65. Hariyanto TI, Intan D, Hananto JE, Putri C, Kurniawan A. Pre-admission glucagon-like peptide-1 receptor agonist (GLP-1RA) and mortality from coronavirus disease 2019 (Covid-19): a systematic review, meta-analysis, and meta-regression. Diabetes Res Clin Pract. 2021;179:109031.

66. Stoian AP, Papanas N, Prazny M, Rizvi AA, Rizzo M. Incretin-based therapies role in COVID-19 era: evolving insights. J Cardiovasc Pharmacol Ther. 2020;25:494-6.

67. Banerjee Y, Pantea Stoian A, Silva-Nunes J, et al. The role of GLP-1 receptor agonists during COVID-19 pandemia: a hypothetical molecular mechanism. Expert Opin Drug Saf. 2021. https://doi.org/10. 1080/14740338.2021.1970744.
68. Abate N, Sallam HS, Rizzo M, et al. Resistin: an inflammatory cytokine. Role in cardiovascular diseases, diabetes and the metabolic syndrome. Curr Pharm Des. 2014;20:4961-9.

69. Longo M, Caruso P, Maiorino MI, Bellastella G, Giugliano D, Esposito K. Treating type 2 diabetes in COVID-19 patients: the potential benefits of injective therapies. Cardiovasc Diabetol. 2020;19:115.

70. Han T, Ma S, Sun C, et al. The association between anti-diabetic agents and clinical outcomes of COVID-19 in patients with diabetes: a systematic review and meta-analysis. Arch Med Res. 2021;S0188-4409(21):00167-73.

71. Khunti K, Knighton P, Zaccardi F, et al. Prescription of glucose-lowering therapies and risk of COVID-19 mortality in people with type 2 diabetes: a nationwide observational study in England. Lancet Diabetes Endocrinol. 2021;9:293-303.

72. Luo P, Qiu L, Liu Y, et al. Metformin treatment was associated with decreased mortality in COVID-19 patients with diabetes in a retrospective analysis. Am J Trop Med Hyg. 2020;103:69-72.

73. Gao Y, Liu T, Zhong W, et al. Risk of metformin in patients with type 2 diabetes with COVID-19: a preliminary retrospective report. Clin Transl Sci. 2020;13:1055-9. 